\title{
Should Vocational Schools be Strategically Located with Relevant Industries to Reduce Graduates' Competency Gaps?
}

\author{
Indah Khoerunnisa* \\ Study Program of Technology and Vocational Education, \\ Post-Graduate School \\ Universitas Pendidikan Indonesia \\ Bandung, Indonesia \\ *indahkhoerunnisa@upi.edu
}

\author{
Didin Wahyudin \\ Department of Electrical Engineering Education \\ Universitas Pendidikan Indonesia \\ Bandung, Indonesia \\ deewahyu@upi.edu
}

\author{
Sri Handayani, Ana A \\ Study Program of Agro-Industrial Technology Education \\ Universitas Pendidikan Indonesia \\ Bandung, Indonesia \\ srihandayani@upi.edu, ana@upi.edu
}

\begin{abstract}
The shrinkage of employment opportunities due to the rapid development of technology requires responsive vocational education in adjusting graduates' competencies needed. This research was conducted to describe the availability of Agroindustry vocational schools with relevant food industries based on the regional potential to reduce the gap in graduate competency. The method used is descriptive qualitative. 47 Agroindustry vocational schools spread in 14 regencies in West Java, and 120 food industries spread across 15 regencies. The low percentage of availability of Agroindustry vocational schools and the food industry is not aligned with the potential of the region that has been established. The availability of vocational schools and relevant industries based on location provides opportunities for vocational schools to collaborate and implement link and match programs. Synchronization of the expertise areas of vocational schools with superior potential areas in each province needs to be identified.
\end{abstract}

Keywords: disparity, vocational schools, food industry, link and match

\section{INTRODUCTION}

The strong cooperative relationship between vocational schools and industry is one indicator of the success of vocational education $[1,2]$. This collaboration is carried out to support several vocational programs that are mutually beneficial for industry or vocational schools, such as internships, job training, industry visits, or other programs held [3]. Vocational schools play an important role by providing competency-based education that has a link and matches with industry needs, while the industry facilitates coaching, providing guidance and vocational development to produce competent industrial workforce $[4,5]$.

Conditions on the field today, the unemployment rate is still dominated by vocational school graduates compared to other levels of education, which amounted to $11.24 \%$ [6], according to the education level completed in percent for one year is presented in Table 1. This phenomenon indicates that there is a supply of labor that is not absorbed, which creates a problem of inequality, especially for graduates of vocational education.

Mismatch of vocational education graduates with industrial needs is caused by many factors, including a mismatch between educational qualifications and employment [7]. Vocational education is considered not flexible enough in responding to industry requests so that the inability of educational institutions to prepare human resources that are qualified in accordance with the reality of the rapid demands of industry [8,9]. In connection with this, the suitability of the vocational education curriculum with industrial needs is still a challenge for developing countries [10]. Collaboration between vocational schools and industry is the key to the success of vocational education because the implementation of education can be designed, implemented and evaluated together so that the relevance of graduates' competencies to the demands of the labor market can increase. Both parties can develop a vocational curriculum together, and the spectrum of vocational skills is tailored to the needs of the industry [11]. 
TABLE I. UNEMPLOYMENT RATE ACCORDING TO THE HIGHEST EduCATION LEVEl COMPLETED, August 2017-August 2018

\begin{tabular}{|l|l|l|l|}
\hline \multicolumn{1}{|c|}{ Education Level } & \multicolumn{1}{c|}{ Aug-17 } & \multicolumn{1}{c|}{ Feb-18 } & \multicolumn{1}{c|}{ Aug-18 } \\
\hline Primary School & $2.62 \%$ & $2.67 \%$ & $2.43 \%$ \\
\hline Junior High School & $5.54 \%$ & $5.18 \%$ & $4.80 \%$ \\
\hline Senior High School & $8.29 \%$ & $7.19 \%$ & $7.95 \%$ \\
\hline Vocational High School & $11.41 \%$ & $8.92 \%$ & $11.24 \%$ \\
\hline Diploma & $6.88 \%$ & $7.92 \%$ & $6.02 \%$ \\
\hline University & $5.18 \%$ & $6.31 \%$ & $5.89 \%$ \\
\hline
\end{tabular}

The spectrum of vocational schools is a reference in the implementation of expertise competencies [12]. 14,218 vocational schools are registered in Indonesia. All vocational schools collectively offer 9 areas of expertise, consisting of 48 skills programs, and 142 skills competencies [13]. Determination of expertise competencies is based on labor market needs, and priority of the region's superior potential, so that it can connect between education and employment [14]. The highest distribution of SMK in Indonesia from 34 provinces in Indonesia is West Java Province. The number of Vocational Schools in West Java Province is 2,937, with details of 287 state Vocational Schools and 2,650 private Vocational Schools [15]. West Java Province is listed as a province that has regional superior potential in the agricultural sector and processing industries. The availability of relevant SMKs and industries in accordance with their competencies is important to ascertain, one way to find out their availability is by mapping to support synchronization of vocational schools with industry needs.

Mapping is defined as a representation of information in a visual or textual form that can link one information with other information [16]. This form of mapping varies depending on the purpose of development and use. School mapping plays an important role in providing information to determine schools according to requirements [17], build school geospatial databases that support infrastructure development, policy analysis, and decision making [18]. School mapping can be done with or without technology. The use of technology can be used to help facilitate the updating of school information [19]. This mapping can be used to describe the distribution of vocational schools and the availability of industries relevant to their field of expertise.

The highest distribution of SMK in Indonesia from 34 Provinces is West Java Province. The number of Vocational Schools in West Java Province is 2,937, with details of 287 state Vocational Schools and 2,650 private Vocational Schools [13]. West Java Province is listed as a province that has regional superior potential in the agricultural sector and processing industries. In the economic structure of West Java, the agricultural sector is the second-largest dominant sector after industry [12]. This potential in the agricultural sector is spread evenly throughout the Regency [20]. In this case, the mapping of Agroindustry Vocational School is needed to determine the distribution of location and its relevance to the availability of food industries in each Regency.

Several countries that have carried out school mapping for various purposes are China [21], UK [22,23], Malta [24], Chili [25], New Zeland [26], Spanyol [27], Inggris [28,29], Minnoseta [30], Myanmar [19], India [18], Aurangabad [17],
Kenya [31], US [32-34], Ghana [35], Malaysia [36], Kanada [37], Hawai [38], Eropa [39,40], and Australia [41]. Literature research results, most of the school mapping studies focus on three things, namely evaluation of school policies or broader policies relating to the evaluation of the education system applied [23,35,40,41] utilization of mapping tools as an infrastructure database [18,19], and school information delivery tools to help prospective users determine school choices [17].

This research was conducted to describe the distribution of vocational schools of agroindustry and the availability of relevant food industries based on the regional potential to reduce the gap in graduate competency. With the presence of the school and industry mapping, it is expected to provide information related to the distribution of vocational schools and industrial distribution in each regency in West Java, so that the link and match between vocational and industry schools can be optimized.

\section{RESEARCH METHOD}

The method used in this study is a descriptive method. The selection of this method is intended to describe the distribution conditions of Agroindustry Vocational Schools with the distribution of food industries in each Regency in West Java, judging from the relevance of their competencies. The approach used in this study is a qualitative approach. A total of 47 agroindustry vocational schools from 278 vocational schools in West Java were scattered in 14 regencies, and 120 food industries spread across 15 regencies.

Mapping is based on documentation studies. Vocational school data is sourced from the official website of the Vocational Principal Data with the address http://datapokok.ditpskm.net, and industry data sourced from the Association of Indonesian Food and Beverage Association (GAPMMI in Indonesia). The principal data of Vocational School is a site that was built with the aim of facilitating interested parties to access Vocational data in Indonesia. The GAPMMI in Indonesia is a business association that was founded in 1976, based on awareness of the importance of advancing the food industry in Indonesia. GAPMMI in Indonesia acts as an institution that bridges the industrial world with the government or related stakeholders, one of them is vocational schools.

\section{RESULTS AND DISCUSSION}

\section{A. Availability of Agroindustry Vocational School and Food Industry}

Agroindustry vocational schools are spread in 14 districts from 27 regencies in West Java, or $51.85 \%$ of districts in West Java have provided agroindustry vocational schools. Compared to the entire field of vocational school expertise in West Java, the number of agroindustry vocational schools is only $1.6 \%$ or 47 agroindustry vocational schools from 2,937 registered vocational schools. The availability of Agroindustry vocational schools is presented in Figure 1. 


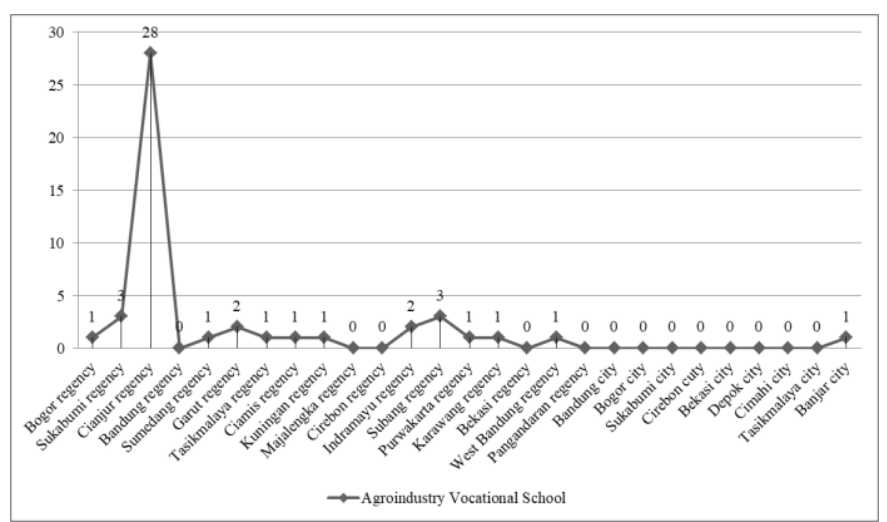

Fig. 1. Availability of agroindustry vocational schools in West Java.

The low percentage of availability of agroindustry vocational schools is not in line with the region's superior potential that has been determined by the government, namely agriculture, processing industry, restaurant services, hotel accommodation services, plantations, livestock, and capture fisheries. The priority of the superior potential of West Java Province is agriculture, processing industry, and community services. Associated with the employment of vocational schools, increasing regional superior potential can affect the number of vocational school graduates' needs so that the absorption of graduates increases in accordance with the development of industries in each region.

Synchronization of the expertise areas of vocational schools with superior potential areas in each province needs to be identified. The regional potential has direct linkages with the level of development, especially the development of education in an area so that the types of regional superior potential become an important part of the economic sectors of a region. Regional superior potential can be related to other sectors, namely the input supply sector (backward linkage) and the user output sector (forward linkage). The development of the region's superior potential can be a driver of the development of other related sectors [42] so that it is expected to provide a large and reliable contribution to the regional economy.

Food industries in West Java that are members of GAPMMI in Indonesia were recorded as 120 out of 381 or $31 \%$ located in West Java. This food industry is spread in 15 regencies. The survey results show that 10 regencies have Agroindustry and food industry vocational schools. The availability of relevant vocational and industrial schools based on location provides opportunities for Vocational Schools to collaborate and implement link and match programs. The availability of the food industry in West Java is presented in Figure 2.

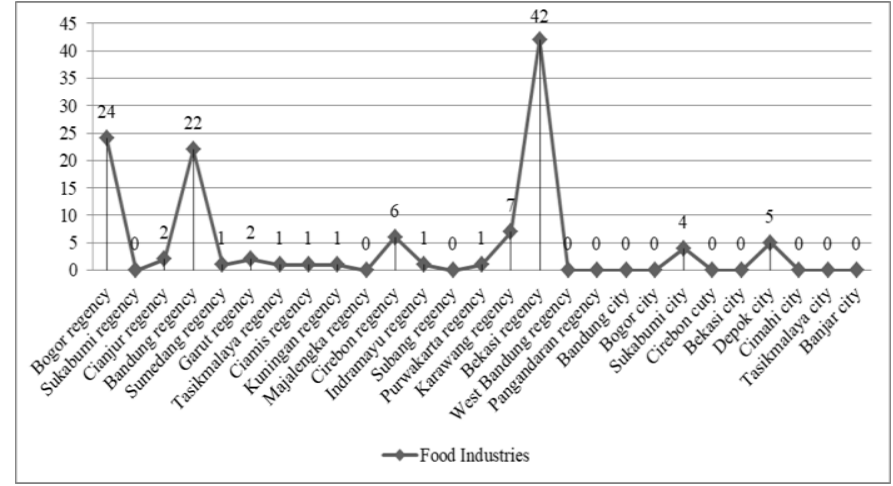

Fig. 2. Availability of food industries in West Java.

Curriculum alignment, implementation of work-based learning in industrial work practices and teaching factory, depends very much on how strong the cooperative relationship between vocational and industrial schools is. It should be a concern for all stakeholders to adjust the availability of vocational schools in accordance with regional potential, and the availability of industries that meet the prerequisites for link and match, so that gaps in graduate competency can be reduced and the number of unemployed graduates decreases. The availability of agroindustry vocational schools and food industries in West Java is presented in Figure 3.

The low availability of agroindustry vocational schools and food industries in West Java that are in accordance with regional potential contribute to the graduates' competencies produced. Programs to develop vocational schools to improve the relevance and quality of graduates' competencies are important to do, based on the availability of vocational schools and the need for labor is still not relevant to the priorities of regional potential. The link and match program is expected to be able to overcome the diversity of labor requirements in Indonesia so that the focus is on improving the quality of workers who cannot run fast. Opportunities for employment and distribution of labor geographically according to the regional potential must be opened.

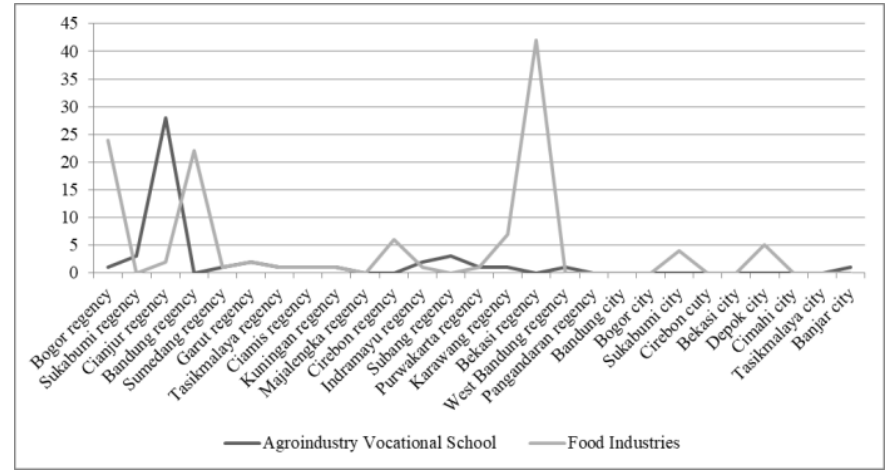

Fig. 3. Availability of agroindustry vocational schools and food industries in West Java. 


\section{B. Link and Match Vocational School with Industry}

The implementation of link and match between vocational school and industry can be achieved by optimizing vocational school cooperation with industry and developing the right curriculum. Collaboration between vocational school and industry is basically a process of conceptual operation of link and match. This collaboration must be able to integrate the strategies and school culture with industry, provide facilities for communication between students and practitioners, support good management processes and structures, have written agreements regarding their respective roles and responsibilities, can be measured, have clearly targeted results, and has a development program for all personnel involved.

Several variations of vocational school collaboration with industry are industrial work practices, industrial classes, training centers, teacher training programs, research collaboration, student certification, special job exchanges or recruitment, product-based education implementation, and factory teaching. To be able to implement this cooperation program, there are prerequisites that must be met, namely the expertise program in vocational schools must be in line with the field of work in the location of industrial work practices, vocational schools must be able to ensure the concept of industrial work practices in accordance with regulations, and be able to determine the criteria for industrial work practices. Link and match optimization between vocational and industrial schools are expected to be able to realize vocational schools as investments in human resources to spur the industrial sector more competitive in the global scope.

\section{CONCLUSION}

The availability of Agroindustry vocational schools and food industries in West Java in line with regional potential needs to be improved. Efforts to build cooperation between vocational schools and industry must be more optimal. Graduate competencies can be improved by developing links and match programs between vocational schools and related industries so that vocational schools can be responsive to industry demand.

\section{REFERENCES}

[1] I. D. A. Nurhaeni, Y. Kurniawan, A. W. Hasyim, and F. P. Hernawan, "A Study of The Impact of Cooperation Between Vocational High School and Industries in Malang City," 2018.

[2] W. Eichhorst, R. N. Planas, R. Schmidl, and K. F. Zimmermann, “A Road Map To Vocational Education And Training In Industrialized Countries," ILR Rev., vol. 68, no. 2, pp. 314-337, 2015.

[3] N. A. Yunikawati, P. H. Prayitno, M. P. Purboyo, N. Istiqomah, and E. Yunika, "Causes and Solution To Reduce Unemployment Vocational School Graduate in Indonesia," UNEJ e-Proceeding, no. November, pp. 200-206, 2018.

[4] Permenperin, "Pedoman Pembinaan dan Pengembangan Sekolah Menengah Kejuruan Berbasis Kompetensi yang Link and Match Dengan Industri." 2017.

[5] A. Bakar, I. Hanafi, U. N. Jakarta, and V. Education, "Assessing Employability Skills of Technical-Vocational Students in Malaysia," J. Soc. Sci., vol. 3, no. 4, pp. 202-207, 2007.
[6] BPS, Keadaan Ketenagakerjaan Indonesia Agustus 2018. 2018, pp. 1-6.

[7] S. D. Cahyanti, M. Indriayu, and Sudarno, "Implementasi Program Link and Match dengan Dunia Usaha dan Dunia Industri pada Lulusan Pemasaran SMK Negeri 1 Surakarta," J. Pendidik. Bisnis dan Ekon., vol. 4, no. 2, 2018.

[8] A. Muhson, D. Wahyuni, Supriyanto, and E. Mulyani, "Analisis Relevansi Lulusan Perguruan Tinggi dengan Dunia Kerja,” J. Econ., vol. 8, no. 1, pp. 42-52, 2012.

[9] I. Hanafi, "Re-Orientasi Keterampilan Kerja Lulusan Pendidikan Kejuruan,” J. Pendidik. Vokasi, vol. 2, no. 1, pp. 107-116, 2012.

[10] N. M. Albashiry, J. M. Voogt, and J. M. Pieters, “Curriculum Design Practices of a Vocational Community College in a Developing Context: Challenges and Needs," Community Coll. J. Res. Pract., vol. 39, no. 12, pp. 1137-1152, 2015.

[11] A. Bakker and S. Akkerman, "The Learning Potential of Boundary Crossing in The Vocational Curriculum," Handb. Vocat. Educ., 2017.

[12] A. Mukhdis, A. B. N. R. Putra, A. M. Nidhom, A. Dardiri, and H. Suswanto, Panduan Sinkronisasi Bidang Keahlian Di SMK Dengan Prioritas Potensi Unggulan Wilayah dan Tenaga Kerja. Jakarta: Direktorat Pembinaan SMK, Kemeterian Pendidikan dan Kebudayaan RI, 2017.

[13] K. Direktorat Pembinaan SMK, Buku Data SMK 2017. 2017.

[14] A. Ait Si Mhamed, "Shaping The Futures of (Vocational) Education and Work: Commitment of VET and VET Research," Int. Rev. Educ., vol. 63, no. 4, pp. 605-607, 2017.

[15] D. Kemendikbud, Data Sekolah Nasional, no. 1. 2018, pp. 2-4.

[16] L. Ervin, B. Carter, and P. Robinson, "Curriculum Mapping: Not as Straightforward as It Sounds," J. Vocat. Educ. Train., vol. 65, no. 3, pp. 309-318, 2013.

[17] S. P. Khobragade and K. . Kale, "School Mapping System Using GIS for Aurangabad City,” Res. J. Pharm. Biol. Chem. Sci., vol. 4, no. 10, pp. 17110-17119, 2016.

[18] S. Agrawal and R. D. Gupta, "School Mapping and Geospatial Analysis of The Schools in Jasra Development Block of India," Int. Arch. Photogramm. Remote Sens. Spat. Inf. Sci., vol. XLI, no. July, pp. 145$150,2016$.

[19] M. M. Sein, S. Z. M. Maung, M. T. Khine, K. Phyo, T. Aung, and P. P. P. Tun, "School Mapping for Schools of Basic Education in Myanmar," Nature, vol. 744, pp. 115-122, 2018.

[20] Badan Penghubung Pemerintah Provinsi Jawa Barat, "Potensi Pertanian Jawa Barat," pp. 7-9, 2018.

[21] J. Rao and J. Ye, "From a Virtuous Cycle of Rural-Urban Education to Urban-Oriented Rural Basic Education in China: An Explanation of the Failure of China's Rural School Mapping Adjustment policy," J. Rural Stud., vol. 47, pp. 601-611, 2016.

[22] J. Arnold, S. Bruce-Low, S. Henderson, and J. Davies, "Mapping and Evaluation of Physical Activity Interventions for School-Aged Children," Public Health, vol. 136, pp. 75-79, 2016.

[23] L. Earl, "Children's food maps: using social mapping to understand School Foodscapes," Ethnogr. Educ., vol. 13, no. 4, pp. 508-528, 2018.

[24] M. Briguglio and A. Debattista, "Mapping The Outcomes of A SchoolBased Cultural Programme," City, Cult. Soc., vol. 11, no. August, pp. 39-49, 2017.

[25] A. Vásquez, K. Marinkovic, M. Bernales, J. León, J. González, and S. Castro, "Children's Views on Evacuation Drills and School preparedness: Mapping Experiences and Unfolding Perspectives,” Int. J. Disaster Risk Reduct., vol. 18, pp. 1-47, 2018.

[26] T. Stewart, J. Schipperijn, B. Snizek, and S. Duncan, “Adolescent school travel: Is Online Mapping a Practical Alternative to GPS-Assessed Travel Routes?,” J. Transp. Heal., vol. 5, pp. 113-122, 2017.

[27] O. Moliner, A. Sales, and A. Sanahuja, "Social Mapping in the Context of a Community-build Day: Strategy to Strengthen Links with Community in a Small Rural School," Procedia - Soc. Behav. Sci., vol. 237, no. June 2016, pp. 305-310, 2017. 
Preventing Childhood Obesity," Procedia - Soc. Behav. Sci., vol. 201, no. February, pp. 102-109, 2015.

[37] J. Y. Y. Kwan, J. Nyhof-Young, P. Catton, and M. E. Giuliani, "Mapping The Future: Towards Oncology Curriculum Reform in Undergraduate Medical Education at a Canadian Medical School,” Int. J. Radiat. Oncol. Biol. Phys., vol. 91, no. 3, pp. 669-677, 2015.

[38] L. J. Hsu, M. Y. Pacheco, C. Crabtree, and J. E. Maddock, "Using Concept Mapping in the Development of a School of Public Health," Hawaii. J. Med. Public Health, vol. 74, no. 7, pp. 224-229, 2015.

[39] T. Xu, H. R. Jäger, M. Husain, G. Rees, and P. Nachev, "The Rise of a New Associationist School for Lesion-Symptom Mapping,” J. Neurol., vol. 141, no. 1, pp. 48-54, 2018.

[40] [40] P. Reiska, K. Soika, and A. J. Cañas, "Using Concept Mapping to Measure Changes in Interdisciplinary Learning During High School," Knowl. Manag. E-Learning, vol. 10, no. 1, pp. 1-24, 2018.

[41] S. Osborne, L. I. Rigney, T. Benveniste, J. Guenther, and S. Disbray, "Mapping Boarding School Opportunities for Aboriginal Students from the Central Land Council Region of Northern Territory," Aust. J. Indig. Educ., pp. 1-17, 2018.

[42] K. Akachi, M. Matsumoto, M. Yasue, N. Nakamura, M. Kamada, and T. Ohno, "Global, Regional, and National Comparative Risk Assessment of 79 Behavioural, Environmental and Occupational, and Metabolic Risks or Clusters of Risks, 1990-2015: A Systematic Analysis for the Global Burden of Disease Study 2015," Neurol. Surg., vol. 388, pp. 1659-1724, 2016.

[36] H. A. M. A. Majid, A. Danis, S. K. A. Sharoni, and M. Khalid, "'Whole School Environmental Mapping Framework and Observation' in 